\title{
Modelling the relationship between LID practices and the runoff of rainwater through the example of rainfall data for Krakow
}

\author{
Joanna $\mathrm{Bąk}^{1, *}$ \\ ${ }^{1}$ CUT Institute of Water Supply and Environmental Engineering, Cracow, Poland
}

\begin{abstract}
The progressing process of urbanization causes areas that were once previously green to turn into areas with a high rate of runoff. For this reason, all activities aimed at the alternative management of rainwater in the city are extremely important. The aim of the work is to compare the share of rainwater management in urban catchments to various alternative forms of management of these waters (including rain gardens and green roofs). The paper compares the outflows from the sample catchment with different runoff coefficients and after the implementation of various Low Impact Development (LID) practices to the catchment. The calculations were carried out using the Storm Water Management Model (SWMM) program version 5.1.012 with LID controls developed by the United States Environmental Protection Agency (US EPA). The rainfall data used to carry out the simulation was derived over the last three years from the meteorological station in Krakow.
\end{abstract}

\section{Introduction}

The progressive process of urbanization results in the size of impervious areas in settlement units significantly increasing. This also means an increase in the runoff coefficient. New investments are created, including those of a commercial and business nature.

At the same time, climate change is taking place in the world, the effects of which are particularly noticeable in cities. The document [1] presents an analysis of trends in climate change in Poland by 2030. The expected annual rainfall amounts do not show any clear trend, however, the increasing frequency of torrential rainfall should be taken into account. Taking into consideration the expected spatial diversification of the climatic conditions in Poland, it should be noted that an increase in the frequency of downpour rains $(>20$ $\mathrm{mm} /$ day) in southern Poland should be expected [1].

For these reasons, it is extremely important to adapt cities to climate change and to intensify all activities aimed at this goal. In 2013, a document [1] was adopted in Poland, which is part of the European Union's policy in adapting Europe to climate change.

The possible effects of the described climate changes in urbanized areas may include local floods and urban floods. In Poland, the nineteenth-century principle of the "end of the pipe" is still predominant, which consists in draining rainwater from the city as quickly as

\footnotetext{
*Corresponding author: jbak@pk.edu.pl
} 
possible [2]. An efficient sewage system with adequate capacity is not a sufficient solution, because the attention should be paid to whether the rainwater receiver is able to receive this amount of rainwater. In addition, adjusting the existing sewage system by increasing its efficiency is a very difficult task, if not impossible within the central parts of cities. It should also be borne in mind that the combined sewage system dominates in the downtown, which means that rainwater directed to the network is mixed with sanitary sewage and then directed to wastewater treatment plants. It is very costly to treatment the volume of wastewater generated by rainwater.

Therefore, it is looking for alternative ways to manage rainwater. Special attention has been given to green infrastructure. From the perspective of one of the documents concerning the adaptation of cities to climate change [3], the creation of green infrastructure is indicated as one of the example adaptation measures for the area at risk of urban flooding. It is treated as a "win-win" option where, while minimizing the sensitivity to the effects of climate change, additional benefits in the social, ecological or economic sphere are obtained [3].

For these reasons, the paper considers the use of selected forms of green infrastructure (green roofs and rain gardens) in urbanized space. The aim of the modelling was to estimate what changes in the outflow from the example catchment can potentially be obtained by implementing sustainable rainwater management systems into an initially impermeable area. The benefits that can be obtained by such modernization were also determined. The rainfall data from one of the cities in southern Poland was used in the simulation.

\subsection{Selected sustainable rainwater management methods}

One of the possibilities of action for the adaptation of cities to the effects of climate change is alternative ways of rainwater management. Recently, the name sustainable water management has started to become adopted in Poland; while in the United States they are called low impact development practices (in short LID) [4]. Sustainable development in the field of rainwater management can be implemented by applying natural management methods, as well as using sewage infrastructure with accompanying appliances [5]. Retention is mainly used for delaying and extending the time of rainwater outflow to receiver's water or to infiltration devices [4]. Among the devices for the sustainable management of rainwater, one can distinguish those that use surface infiltration, infiltration with underground retention, infiltration with surface retention and only retention (without infiltration) $[4,8]$.

Green roofs and rain gardens belong to the bioretention systems using infiltration with surface retention [4]. They are included in LID practices. Green roofs are a solution widely discussed in the technical literature, and works $[4,5,6,7,8,9,10,11]$ can be given as examples. There are also guidelines and design rules [i.e. 12, 13]. Green roofs can be defined as places on the structure of buildings that recreate natural ground conditions and allow the permanent creation of biologically active areas [6]. They consist of several layers together with the ground soil on which vegetation is planted [4]. They can reduce the outflow of rainwater to the sewage system by up to $100 \%$ [6].

Another LID practice is rain gardens, which are gradually gaining more popularity. As an example, in 2015 in Lodz six rain gardens was realized near facilities available to the public $[3,14]$. Rain gardens are made as natural or artificial depressions which retain water in a temporary manner [4]. They are mainly used to manage rainwater flowing from the surface up to 1 hectare. Rain gardens are used as solutions for taking over the flow, for example from parking lots or a shared zone [6]. They allow for the management of rainwater in the place of precipitation through its infiltration into the soil [4]. Their task is the storage of water during rainfall and groundwater supply through infiltration and 
improvement of outflow quality [6]. This LID practice minimize the amount of rainwater entering the sewage system [4].

According to the documentation of the simulation program [15], rain gardens are types of bio - retention cells consisting only of the designed layer without a gravel bed below them. Rain gardens with a more complex structure are often simply called bioretention cells [16].

\subsection{Software for rainwater runoff quantity simulation}

In the 21 st century, the modelling of various phenomena and processes is an indispensable tool supporting planning, design and management in civil and environmental engineering. Modelling to assess the hydraulic performance of alternative forms of rainwater management is a task supporting their introduction into urban space. There are many programs that allow the simulation of outflow from catchments, both free and commercial.

One of the most popular modeling applications is the software of the United States Environmental Protection Agency - Storm Water Management Model (US EPA SWMM). It is a dynamic rainfall - runoff simulation model allowing, among other things, the simulation of the outflow from a basin [15]. This application can be used not only to support the design and analysis of rainwater drainage, but also the combined and sanitary sewerage [15, 17]. From version 5.0.019, LID controls are available in the program. Currently, this program enables the modeling of eight forms of green infrastructure (LID practices). These include [15]:

- green roofs

- rain gardens

- rain barrels or cisterns

- bioretention cells (or bio-swales)

- vegetative swales

- infiltration trenches

- rooftop (downspout) disconnection

- continuous permeable pavement systems.

An interesting solution is also the utility of the software in the form of a Climate Adjustment Tool (CAT). This tool makes it possible to incorporate future climate change projections into the model [18]. Also important in the program are various approaches to taking into account the role of permeable surfaces in the modelled catchment. LID controls can be introduced in two ways - locating them in an existing catchment or creating a new catchment for them. An alternative method is to use Sub-Area Routing. Thanks to this function, it is possible to direct the outflow from impermeable surfaces to the permeable catchment surfaces, and only then to the outflow. This approach allows green infrastructure practices modeling, but it is not as flexible as creating an additional catchment [19].

Another program that allows the modelling of selected forms of green infrastructure is The Green Infrastructure Flexible Model (in short GIFMod). It allows the creation of conceptual models of selected forms of green infrastructure for predicting their hydraulic performance. With its help, it can be modelled, among others, bioretention, green roofs, vegetated swales or rain barrels [20]. More information could be found in the work [21].

\section{Research methodology}

Rainfall data was obtained free of charge from the Institute of Meteorology and Water Management - National Research Institute (IMGW-PIB) in Warsaw [22]. The analysed data covered 10 - minute sums of rainfall in Kraków from the Wola Justowska station over the last three years, that is the period from January 1, 2015 to December 31, 2017. On their 
basis, a graph of precipitation dependence over time was made. Then, the rainfall event in which the highest 10 minutes sum of precipitation occurred was selected. The rainfall data subjected to initial analysis is shown in Fig. 1. For modeling, the rain was selected from July 20, 2015, which took place from 1:40 pm to 2:00 pm. Rainfall occurred both before and after the described precipitation. Due to the very short breaks (not exceeding 30 minutes) - they were also included in the simulation. The total amount of precipitation was $51.6 \mathrm{~mm}$, and their duration covered 110 minutes (with breaks) from 1:20 pm to 3:10 pm.

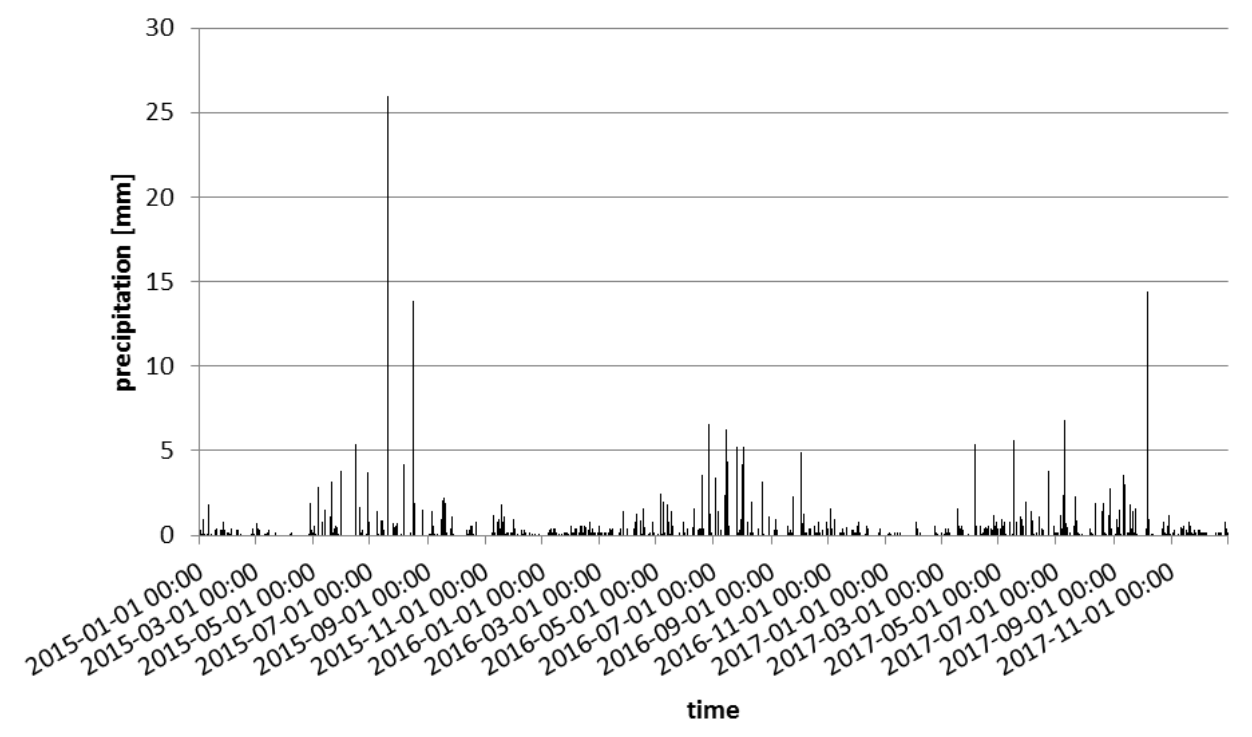

Fig. 1. A graph showing 10-minute sums of precipitation from the Wola Justowska station in Kraków for the period January 1, 2015 - December 31, 2017. Own elaboration based on data from [22].

The standard Microsoft Office Excel software was used for the rainfall analysis, while the United States Environmental Protection Agency's Storm Water Management Model, version 5.1.012 downloaded from [16] was used for modeling.

Due to the presence of a large number of shopping centres in the city with surrounding areas containing a high runoff coefficient, an exemplary catchment with an area of 1.5 ha was adopted for simulation. It was assumed that it is the location of a shopping centre with $10050 \mathrm{~m}^{2}$ of building area and a car park. Estimates of the lot area and retail facility were based on publication [23]. For simplicity, the original runoff coefficient of 1.0 was assumed (completely impervious catchment). It was also settled that the catchment is served by the separate sewerage system. Only the separate storm sewer system is included in calculations.

Four variants were adopted for which calculations were carried out. A catchment was prepared for each variant. An impervious catchment (subcatchment A1) was introduced with a runoff coefficient of $100 \%$ and a catchment with a green roof for $67 \%$ of the area, which corresponds to the building area (A2 subcatchment). This green roof had a layer of soil located on a special drainage mat. The soil layer thickness was assumed to be $76.2 \mathrm{~mm}$. Its porosity was 0.5 and the wilting point 0.05 (as fractions). The thickness of drainage mat was $50 \mathrm{~mm}$. In addition, a third catchment was created with a rain garden on $10 \%$ of its surface (A3). The garden was implemented in the parking lot as 4 similar units with a width of $5 \mathrm{~m}$. It has been assumed that $10 \%$ of the runoff from the impervious surface will be directed to this form of green infrastructure. In addition, another catchment was added (A4), where the green roof was implemented with the rain garden together. Each catchment occupies the same total area. The green roof and rain garden were introduced into the 
existing catchment as LID controls. The size of the introduced forms of green infrastructure differ, which results from the adaptation to the assumed possibilities of their implementation in the catchment. The rainwater drainage system for each variant of the catchment is the same and consists of a two circular conduits with a diameter of $700 \mathrm{~mm}$ arranged with a slope. Rainwater flows through the sewer to the open channel marked as the outfall. The runoff from each catchment was a simulated response to a rainfall event with a total height of $51.6 \mathrm{~mm}$ and a duration of 110 minutes.

\section{Results}

On the basis of the adopted methodology, input data for the EPA SWMM application for four variants of the basin were introduced and simulations were carried out. Due to the use of green infrastructure and the possible extension of the outflow time from the catchment, a simulation period of four hours was assumed. The beginning of the rain is also the beginning of the simulation. In order to minimize continuity errors, a small time interval was used. Dynamic Wave was chosen as the Flow Routing Method. The absolute value of continuity errors did not exceed $0.15 \%$.

Fig,. 2 presents a comparison of the rainwater runoff from three catchment variants (A1, A2 and A3) including a plot of land with a shopping facility and a car park. The graph was generated by the EPA SWMM software.

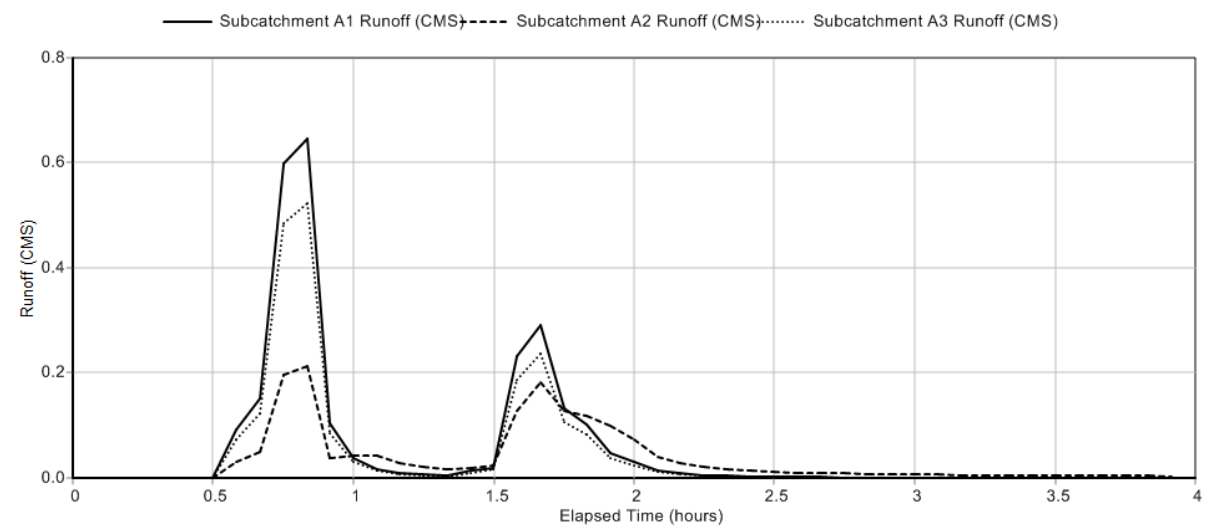

Fig. 2. Comparison of a graph of the rainwater runoff from three catchment variants (A1, A2 and A3) with a shopping centre and a parking lot, using EPA SWMM software.

Capacity of main sewers was sufficient for the maximum flows. No surcharged effects occurred. In analysing the obtained simulation results, it can be noted that the flow in the separate storm sewer system of the subcatchment with the rain garden (A3) disappears after 30 minutes from the end of the downpour and into the impermeable catchment (A1) 5 minutes later. The flow in the drainage channel from the catchment with a green roof disappears only after 1 hour 35 minutes from the end of the rainfall. In Fig. 2, it can be seen that after about 3.5 hours of simulation no flow is observed. The introduced forms of green infrastructure have caused a significant reduction in the peaks of the runoff. For the peak of rainwater flow a reduction of over $67 \%$ for green roofs and by $20 \%$ for rain gardens was obtained. The reduction of the total runoff has also been achieved. It was almost $20 \%$ in the case of the rain garden and over $34 \%$ in the case of the green roof.Taking into account that the surface of the entered rain gardens constitutes only $15 \%$ of the green roof area - they are also an effective solution. Unfortunately, the downside is the fact that there is no possibility of introducing rain gardens on surfaces comparable in size to the green roof in the analysed 
case. It should be noted that the outflow from the catchment with the green roof generally and significantly reduced the outflow from the catchment, however at the end of the simulation the flow was slightly larger than the outflow from the sealed catchment. This is caused by the extended outflow time from the green roof. Confining walls of green roof were present, but overflow did not occur. Berm height was assumed above $75 \mathrm{~mm}$.

Fig. 3 presents a comparison of graphs of the rainwater runoff from two catchment variants (A1 and A4) with a shopping centre and parking lot, using SWMM EPA software. In the case of the intensification of rainwater management using green infrastructure, i.e. the introduction of a green roof and rain garden (subcatchment A4), the peak runoff from the catchment was reduced to the value of $23 \%$ of flow from the impervious catchment. The flow in the sewer disappeared after the same time as in the case of using only the green roof. Equipping the catchment with the green roof and the rain garden resulted in a reduction of the peak flow by over $28 \%$ in relation to the use of only the green roof. When applying certain LID practices, it is possible to consider reducing the capacity of the originally adopted rainwater channel.

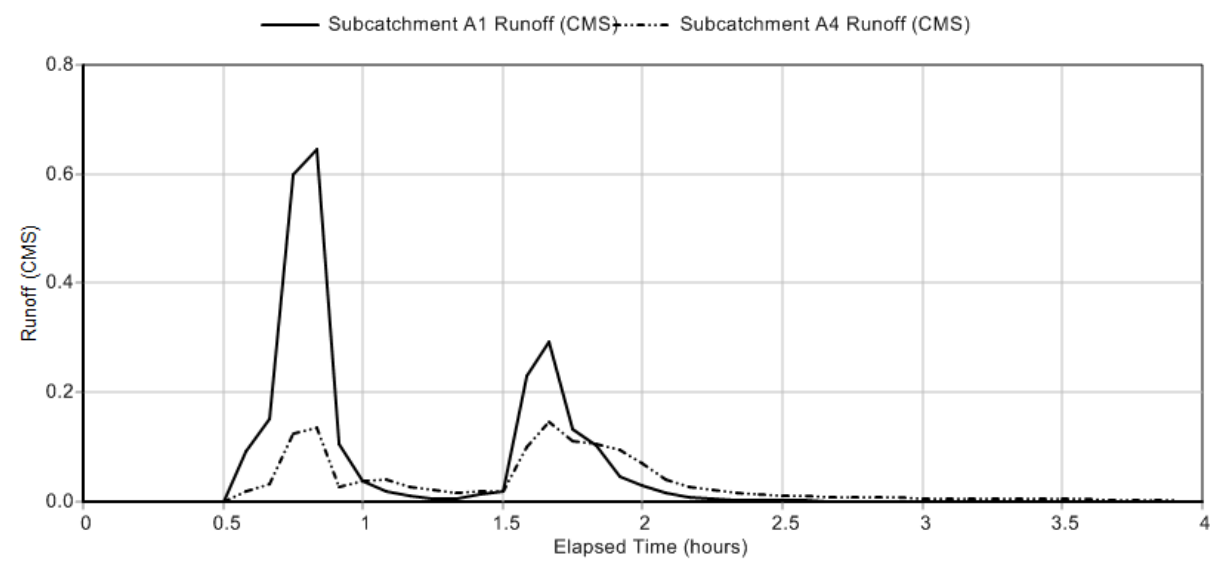

Fig. 3. Comparison of a graph of the rainwater runoff from two catchment variants (A1 and A4) with a shopping centre and car park, using EPM SWMM program.

\section{Summation and conclusions}

The study showed what impact the introduction of LID practices could have on the existing impermeable catchment. It was confirmed in the simulations that LID practices have an essential impact on the rainwater runoff from the catchment and the parameters of functioning of the sewage system (especially flow rate).

The use of alternative methods of rainwater management resulted in a significant reduction of the peak flow in the sewage system. In addition, a reduction in the amount of rainwater directed to the sewerage system was obtained. The introduction of a larger number of sustainable rainwater management systems in a given area results in a distinct decrease of peak flows and a reduction of the rainwater quantity directed to the sewerage system.

It should be borne in mind that not every LID practice can be applied anywhere and on any large catchment area. For example, it is not possible to use a rain garden in the analyzed catchment in such a large area as a green roof. This would result in the loss of parking spaces.

The parameters determining the conditions for the implementation and functioning of a given LID practice in the basin are of key importance in the reduction of peak rainwater 
flow. When using some LID practices, it is possible to consider reducing the diameter of the originally designed sewer.

The modeling the runoff of rainwater with the use of the software like the EPA SWMM can be an auxiliary tool in estimating the outflow from the catchment and making decisions on the choice of rainwater management in a particular area. The software allows, among other things, checking the functioning of the sewerage system when introducing a given rainfall event.

\section{References}

1. Strategiczny plan adaptacji dla sektorów i obszarów wrażliwych na zmiany klimatu do $\begin{array}{lllllll}\text { roku } 2020 \mathrm{Z} & \text { perspektywą do roku } 2030 \text { (SPA2020) }\end{array}$ https://www.mos.gov.pl/fileadmin/user_upload/SPA_2020.pdf

2. P. Kowalczak, Zintegrowana gospodarka wodna na obszarach zurbanizowanych. Część pierwsza: Podstawy hydrologiczno - środowiskowe, Wydawnictwo ProDRUK, Poznań

3. Ministerstwo Środowiska, Podręcznik Adaptacji dla miast, wytyczne do przygotowania Miejskiego Planu Adaptacji do zmian klimatu, http://klimada.mos.gov.pl/dokumenty

4. E. Wojciechowska, M. Gajewska, N. Żurkowska, M. Surówka, H. Obarska Pempkowiak, Zrównoważone systemy gospodarowania wodą deszczową, Wydawnictwo Politechniki Gdańskiej, (2015)

5. D. Słyś, Zrównoważone systemy odwodnienia miast, Dolnośląskie Wydawnictwo Edukacyjne (2013)

6. J. Królikowska, A. Królikowski, Wody opadowe. Odprowadzanie, zagospodarowanie, podczyszczanie i wykorzystanie, Wydawnictwo Seidel - Przywecki Sp. z o.o., (2012)

7. E. Szajda - Birnfeld, A. Pływaczyk, D. Skarżyński, Zielone dachy, Zrównoważona gospodarka wodna na terenach zurbanizowanych, Wrocław (2012)

8. E. Burszta - Adamiak, Zielone dachy jako element zrównoważonych systemów odwadniających na terenach zurbanizowanych, Wydawnictwo Uniwersytetu Przyrodniczego we Wrocławiu, Wrocław (2014)

9. M. Mrowiec, Zielone dachy jako element zrównoważonych systemów odprowadzania wód opadowych, in Problemy zagospodarowania wód opadowych, red. J. Łomotowski, Wydawnictwo Seidel - Przywecki, Wrocław (2008)

10. A. Januchta - Szostak, Woda w miejskiej przestrzeni publicznej. Modelowe formy zagospodarowania wód opadowych i powierzchniowych, Wydawnictwo Politechniki Poznańskiej, Poznań (2011)

11. R. Stifter, Dach gärten. Grüne Inseln in der Stadt, Verlag Eugen Ulmer

12. Kania A., Mioduszewska M., Płonka P., Rabiński J.A., Skarżyński D., Walter E., Weber - Siwirska M. „Zasady projektowania i wykonywania zielonych dachów i żyjących ścian. Poradnik dla gmin”, Stowarzyszenie Gmin Polska Sieć „Energie Cités", Kraków (2013)

13. E. Burszta-Adamiak - red., Dachy zielone. Wytyczne do projektowania, wykonywania i pielęgnacji dachów zielonych - wytyczne dla dachów zielonych, DAFA, Opole (2015)

14. http://www.sendzimir.org.pl/lodzkie-ogrody-deszczowe

15. L. A. Rossman, Storm Water Management Model User's Manual Version 5.1, EPA600/R-14/413b Revised September (2015)

16. https://www.epa.gov/water-research/storm-water-management-model-swmm 
17. S. A. Lowe, S. A., Computer Applications in Engineering Education, 18, 203-212 (2010)

18. L. A. Rossman, SWMM - CAT User's Guide, EPA/600/R-14/428, 2014

19. J. Gironás, L.A. Roesner, J. Davis, Storm Water Management Model Application Manual, EPA/600/R-09/000, (2009)

20. http://gifmod.com

21. A. Massoudieh, M. Maghrebi, B. Kamrani, C. Nietch, M. Tryby, S. Aflaki, S. Panguluri, Environmental Modelling \& Software, vol. 92, 57-73 (2017)

22. Rainfall data from the Institute of Meteorology and Water Management - National Research Institute in Warsaw

23. M. Rutkowski, A. Skarzyński, Civil and Environmental Engineering, vol. 2, 645 - 649 (2011) 